Keywords:

Biofilm

Hypromellose

Casting

Cassava starch

Historic:

Received 05/02/2017

Accepted 26/12/2017

Palavras chave: Biofilme

Hipromelose

Nanofibras

Amido de mandioca

+Correspondence: joabeljr@hotmail.com

DOI:
Ney Robson Taironi do Prado', Joabel Raabe ${ }^{2+}$, Seyedmohammad Mirmehdi', Lisiane Nunes Hugen', Lidiane Costa Lima', Alcinéia de Lemos Souza Ramos', Mário Guimarães Junior ${ }^{3}$, Gustavo Henrique Denzin Tonoli'

\section{STRENGTH IMPROVEMENT OF HYDROXYPROPYL METHYLCELLULOSE/ STARCH FILMS USING CELLULOSE NANOCRYSTALS}

ABSTRACT: Interest in cellulose nanocrystals obtained from natural resources has grown mainly because of features that such materials provide when inserted into polymeric matrices. The present study aimed to evaluate the effect of cellulose nanocrystals addition on mechanical properties of biofilms made from hypromellose (or hydroxypropyl methylcellulose - HPMC) and cassava starch blends (CS). The cellulose nanocrystals were produced by acid hydrolysis and characterized by optical microscopy (OM), transmission electron microscopy (TEM), X-ray diffraction (XRD) and thermogravimetry (TG). Films were made with pure CS, pure hypromellose and also with blends of CS and hypromellose by casting. Then cellulose nanocrystals were added to the blends in the concentrations of 1,3 and $10 \%$ $(\mathrm{m} / \mathrm{m})$. Evaluations of the films included tensile performance and fracture surface by scanning electron microscopy (SEM). It was observed that the reinforcement with nanocrystals improved the mechanical properties of the films, and their fracture surface showed that cellulose nanocrystals promoted an improvement in the cohesion of the hypromellose and starch molecules in the blend, and created a more homogeneous surface.

\section{MELHORANDO A RESISTÊNCIA DE FILMES DE HIDROXIPROPIL METILCELULOSE/ AMIDO COM NANOCRISTAIS DE CELULOSE}

RESUMO: $O$ interesse em nanocristais de celulose obtidos a partir de recursos naturais tem crescido principalmente devido a características que esses materiais fornecem quando inseridos em matrizes poliméricas. $O$ presente estudo teve como objetivo avaliar o efeito da adição de nanocristais de celulose nas propriedades mecânicas dos biofilmes feitos a partir de hipromelose (ou hidroxipropil metilcelulose - HPMC) e misturas com amido de mandioca (CS). Os nanocristais de celulose foram produzidos por hidrólise ácida e caracterizados por microscopia óptica (OM), microscopia eletrônica de transmissão (TEM), difração de raios $X(X R D)$ e termogravimetria (TG). Os filmes foram feitos por fundição (ou "casting") com CS puro, hipromelose pura e também com misturas de CS e hipromelose. Em seguida, os nanocristais de celulose foram adicionados às misturas nas concentrações de I, 3 e $10 \%(\mathrm{~m} / \mathrm{m})$. As avaliações dos filmes incluíram a resistência a tração e a superfície da fratura por microscopia eletrônica de varredura (SEM). Observouse que o reforço com nanocristais de celulose melhorou as propriedades mecânicas, e as observações da superfície de fratura dos filmes testados mostraram que os nanocristais promoveram uma melhora na coesão da hipromelose e do amido na mistura e promoveram uma superfície mais homogênea. 


\section{INTRODUCTION}

Plastic wastes derived from petroleum became a source of concern in large urban areas, once their production on large scale, in most cases, and deposition in unsuitable environments generate numerous urban pollution disorders (AYDIN; ILBERG, 2016). The consumption of polymeric materials in the world has been growing for decades because of their low cost, good mechanical strength, impermeability and transparency, when compared to other materials. The high consumption of polymeric materials and the need to reduce the damage caused by the incorrect deposition of these materials became a major incentive for development of cellulosebased composites for a wide variety of applications.

Cellulose nanofibers can be obtained from different sources and procedures (SIQUEIRA et al., 2009; TONOLI et al., 2012; TONOLI et al., 2016). The term cellulose nanocrystals or "whiskers" is used to label elongated crystalline rod-like nanofibers obtained by acid hydrolysis under controlled period of time and temperature. The acid hydrolysis is selective on degradation of amorphous holocellulose, resulting in colloid suspensions of welldefined cellulose nanocrystals (ALEMDAR; SAIN, 2008). Cellulose nanofibers have been studied for a myriad of applications, such as biofilms (GUIMARÃES JR. et al., 20I5; BUFALINO et al., 20I5a; BUFALINO et al., 20I5b; SCATOLINO et al., 20I7a; SCATOLINO et al., 20I7b), reinforced papers (LAVOINE et al., 20I4; MIRMEHDI et al., 2017), nano-metal complexes (DONIA et al., 20I2; GUPTA et al., 2013; ARANTES et al., 2017), hybrid materials (FORTUNATI et al., 2014; RAABE et al., 2014; RAABE et al., 20I5), biomedical products (SVENSSON et al., 2005; NIKOLAJASKI et al., 20I2) and fiber-cements (FONSECA et al., 2016).

Recently, research works are exploring natural biopolymers for the development of environment friendly bio-based composites derived from renewable resources, in order to provide important contributions for reduction of the impact of fossil fuels use (KANMANI; RHIM, 20I4; SHOJAEE-ALIABADI et al., 2013; GILFILLAN et al., 2016; TEODORO et al., 20I5; ROMERO-BASTIDA et al., 20I5), and aiming to the enhanced biodegradability, edibility and sustainability of the products (SHIT; SHAH, 20I4). Polysaccharides, proteins, and lipid materials from plant and animal sources are usually applied for this purpose.

Among the alternatives studied, the use of starch is prominent, which is an organic polysaccharide widely found in plants, mainly in roots, tubers, seeds and fruits in the form of insoluble granules (ROMERO-BASTIDA et al., 2015). Starch granules are composed of two polysaccharides of D-glucose, amylose and amylopectin, which have different structures and properties and is represented by amorphous regions (amylose and amylopectin branching points) and crystalline regions of amylopectin (AVEROUS; BOQUILLON, 2004; ROMERO-BASTIDA et al., 20I5). Amylose is a linear polysaccharide made of $\alpha-(1-4)$ bound $D$-glucose molecules, with a very low number of $\alpha-(I-6)$ linked branches. Amylose has a helical $\alpha$-helix structure formed by hydrogen bonds between the hydroxyl radicals of glucose molecules (PEREZ; BERTOFT, 20I0). Amylopectin is larger macromolecule than amylose, formed by chains having $\alpha-(I-4)$ bonds and $\alpha-(I-6)$ branches. These branches have a length of 20 to 25 chains (PEREZ; BERTOFT, 20I0). High availability, low cost and biodegradability are aspects that favor the widespread use of starch for materials development (ROZ et al., 2012; MARTINEZ et al., 2009; PRACHAYAWARAKORN et al., 20I0). However, the main obstacles to the widespread use of starch for plastics production are its limited mechanical strength and its high moisture adsorption capacity.

The hypromellose polymer from vegetable source is a cellulose ether in which the hydrogen atoms and hydroxyl groups were partially replaced by alkyl groups, in order to modify the characteristics of native cellulose. Hypromellose is a hydrophilic polymer composed of units of $\beta(I-4)-D$-glucose linked by glycoside bonds. It has been used as a matrix for controlled drug release and gel-forming aqueous medium. Other applications have been assigned to hypromellose, such as stripping agents for paints, adhesives, cosmetics, coatings, protective colloid, stabilizer, suspending agent, thickener, film former and textile products (CHOl et al., 20l6).

Various studies have been developed with different kinds of biodegradable matrices reinforced with fibers and products of vegetable source, which led to improvements on mechanical, physical and barrier properties (KU et al., 20I I; YAN et al., 20I5a; YAN et al., 20I5b). These properties are the main variables that may compromise the application of starch in the plastics sector. Then, polymer blending is an important strategy that may be adopted in order to reduce mechanical and physical limitations of biodegradable polymers and expand their range of applications (YAN et al., 20I5a).

Therefore, the objective of this study was to evaluate the effect of the addition of cellulose nanocrystals on mechanical properties of biofilms made from hypromellose and cassava starch (CS) blends.

\section{Material and methods}

Bleached cellulose Kraft pulp from Eucalyptus urograndis obtained from a commercial source (Brazil) containing approximately $99 \%$ of holocellulose (cellulose + hemicellulose) was used in this experiment. The cellulose fraction was composed of around 92.2 
wt.\% $\alpha$-cellulose, 6.9 wt.\% $\beta$-cellulose and 0.9 wt.\% Y-cellulose, according to TAPPI T 203 cm-99 (2009) standard. Its hemicelluloses (SCAN C 4:6I, I96I) and lignin (SCAN C I:77, I977) contents were of around I3.9 wt.\% and 0.I wt.\%, respectively. Extractives (SCAN C $7: 62,1962$ ) and ash (SCAN C 6:62, 1962) content were of around 0.1 wt. $\%$ and $0.6 w t . \%$, respectively.

Industrial cassava starch (CS) was obtained from the Agroindustrial e Comercial Indy LTDA. The amylose and amylopectin content was determined by iodometry (MARTÍNEZ; CUEVAS, 1989). The ash content was determined by incinerating the material in the oven at $550^{\circ} \mathrm{C}$, according to Protocol No. 923.03 of the Association of Official Analytical Chemists (AOAC, 2000) and the humidity was calculated according to Protocol No. 945. I5. The residual protein content was determined by the Kjeldahl method (1883). The conversion factor used was 6.25 according procedure 2055 (AOAC). The procedure used to determine lipid was based on weight loss of the material subjected to extraction in a soxhlet extractor with petroleum ether according to Gonçalves et al. (2014).

It was used the hypromellose (hydroxypropyl methylcellulose - HPMC) Celotex K60 obtained from Aditex Indústria e Comércio de Aditivos LTDA. The supplied hypromellose had purity of approximately $95 \%$, according to data provided by the manufacturer. This polysaccharide was characterized according to their ash content, moisture, protein, sugars and lipids (ZENEB; PASCUET, 2005).

\section{Preparation and characterization of the cellulose nanocrystals}

Cellulose nanocrystals were obtained by acid hydrolysis process of bleached kraft Eucalyptus pulp (Figure I). The bleached pulp was ground (FRITSCH
Pulverisette mill) and hydrolyzed with sulfuric acid $65 \%$ $(\mathrm{m} / \mathrm{m})$ at $45^{\circ} \mathrm{C}$ for approximately $30 \mathrm{~min}$ under constant stirring (SIQUEIRA et al., 2009; TONOLI et al., 20I2). After hydrolysis, the resulting suspension was centrifuged for $10 \mathrm{~min}$ at a speed of approximately 10,000 rpm and the supernatant removed posteriorly. The material was washed in distilled water and neutralized by the dialysis process to achieve a $\mathrm{pH}$ between 6 and 7 , under continuous flow of water, and then centrifuged at 1,000 rpm for $10 \mathrm{~min}$. The collected supernatant was centrifuged again at 5,000 rpm for $10 \mathrm{~min}$. After these steps, the precipitate containing the cellulose nanocrystals was collected and characterized.

The morphology of nanocrystals was characterized using light microscopy (LM), An Olympus BX5I (Japan). The suspension of cellulose nanocrystals were dried on Petri dishes at $30^{\circ} \mathrm{C}$ for $48 \mathrm{~h}$, these films were then redispersed in distilled water in order to view the agglomerates in the light microscope. The suspensions were stained with a drop of ethanol-safranin-astrablue in order to increase the contrast between the phases. The measurements were performed with image analysis software (Image-ProPlus 5-1.0.20, CYBERMETRICS MEDIA, 2004).

Nanocrystals were evaluated in a transmission electron microscope (TEM) TecnaiTM G2 F20, and samples were prepared with a dilute suspension of cellulose nanocrystals and uranyl acetate as colorant were submitted to sonication (Branson 450) for $2 \mathrm{~min}$. One suspension drop was deposited over a copper grid with Formvar film (400 mesh - Ted Pella) and kept in desiccator for $24 \mathrm{~h}$ for drying before use in TEM analysis. The diameter and length were determined using digital

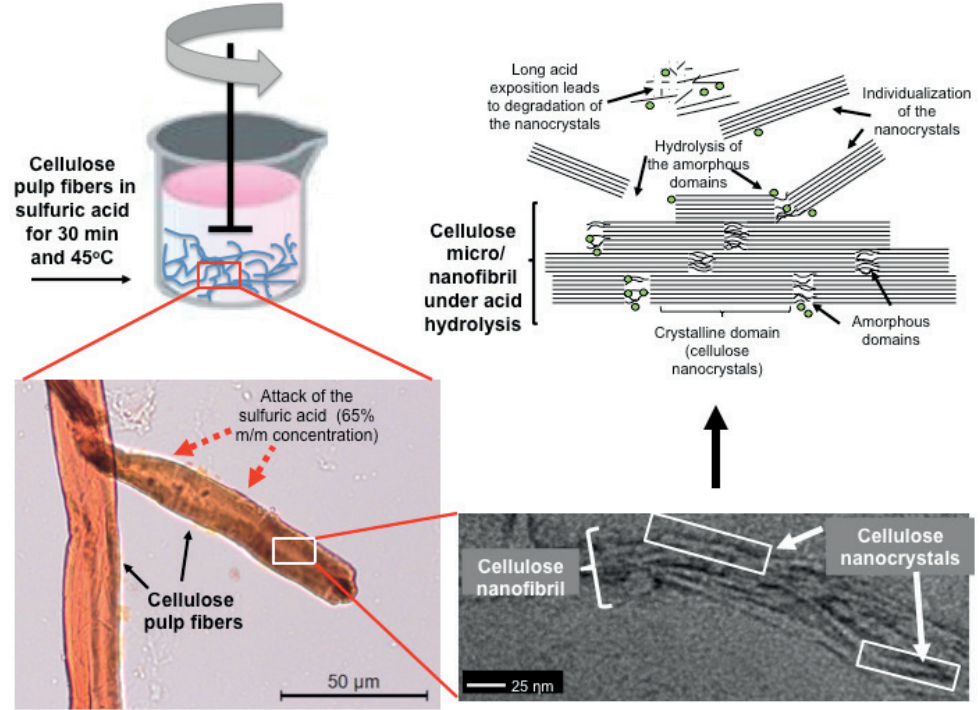

FIGURE I Scheme of the acid hydrolysis of the cellulose pulp fibers, with the individualization of the cellulose nanocrystals. 
image analysis (Image-ProPlus 5-I.0.20, Cybermetrics Media, 2004). A minimum of 100 measurements was carried out to determine the distribution of diameter and length of the cellulose nanocrystals.

The X-ray diffraction (XRD) was applied to verify possible structural changes in the pulp, using an X-ray diffractometer (Shimadzu XRD-6000) with CuKa radiation at $30 \mathrm{kV}$ and $30 \mathrm{~mA}$. The dispersed radiation was detected in the range of $2 \theta=5-40^{\circ}$ at a scan rate of $1^{\circ} \cdot \mathrm{min}^{-1}$. The crystallinity index (Cl) was estimated by Buschle-Diller-Zeronian equation (BUSCHLE-DILLER; ZERONIAN, 1992), from the heights of the $(200)$ peak $\left(2 \theta \sim 22.5^{\circ}\right)$ and the minimum intensity between the $(200)$ and $(110)$ peaks $\left(2 \theta\right.$ between $18^{\circ}$ and $\left.22^{\circ}\right)$.

Thermal stability of the cellulose nanocrystals was investigated in a thermal analyzer TG-DTA Shimadzu $60 \mathrm{H}$. The thermogravimetry was performed in a 4-6 mg sample, heated from $25^{\circ} \mathrm{C}$ to $600^{\circ} \mathrm{C}$ under an atmosphere of nitrogen, using a flow of $50 \mathrm{~mL} \cdot \mathrm{min}^{-1}$ with a heating rate of $10^{\circ} \mathrm{C} \cdot \mathrm{min}^{-1}$.

\section{Production of the films/nanocomposites}

The aqueous suspension of cellulose nanocrystals was prepared in an Ultra Turax model T25 homogenizer (SIQUEIRA et al., 2009), to 20,000 rpm, and subsequently sonicated (BONDESON et al., 2006) in a sonicator operating at $80 \%$ of power under an ice bath, aiming to dispersion of cellulose nanocrystals. The total energy estimated in the process was approximately $24 \mathrm{~kJ}$ for 6 min. The suspensions of nanocrystals were then added to the polymeric matrix (formed by mixing cassava starch and hypromellose) at concentrations of I, 3 and 10\% (dry mass) in relation to dry mass of the matrix. Table I shows the different treatments and codes that will be used throughout this study.

TABLE I Mix design of the treatments (films or solutions) and their codes.

\begin{tabular}{lc}
\hline Samples & Codes \\
\hline Hypromellose & $\mathrm{H}$ \\
Cassava starch & $\mathrm{A}$ \\
Blend 1:9 hypromellose and cassava starch & $\mathrm{B} 1: 9$ \\
Blend 9:1 hypromellose and cassava starch & $\mathrm{B} 9: 1$ \\
Blend 1:1 hypromellose and cassava starch & $\mathrm{B} 1: 1$ \\
$\begin{array}{l}\text { Blend 9:1 hypromellose and cassava starch }+ \\
\text { 1\% cellulose nanocrystals }\end{array}$ & $\mathrm{B} 9: 1-1 \%$ \\
$\begin{array}{l}\text { Blend 9:1 hypromellose and cassava starch }+ \\
\text { 3\% cellulose nanocrystals }\end{array}$ & $\mathrm{B} 9: 1-3 \%$ \\
$\begin{array}{l}\text { Blend 9:1 hypromellose and cassava starch }+ \\
\text { 10\% cellulose nanocrystals }\end{array}$ & $\mathrm{B} 9: 1-10 \%$ \\
\hline
\end{tabular}

The cassava starch solution was prepared with 3 $\mathrm{g}$ of the sample solubilized in $90 \mathrm{~g}$ of distilled water at constant stirring of $500 \mathrm{rpm}$ for $10 \mathrm{~min}$. $20 \%$ glycerol (based on dry weight of starch) was diluted with distilled water until the final weight reached $10 \mathrm{~g}$. Then, glycerol was incorporated into the starch solution, with total of $100 \mathrm{~g}$ of solution at the end of the process. The mixture was heated in a microwave oven until a temperature of $80^{\circ} \mathrm{C}$, then removed and hold under heating at $78^{\circ} \mathrm{C}$ and constant stirring of I,200 rpm for $10 \mathrm{~min}$.

The hypromellose solution was prepared using 2 $\mathrm{g}$ of material solubilized in $90 \mathrm{~mL}$ of solution containing water and ethanol ( $I: I)$ stirring of I,200 rpm for $10 \mathrm{~min}$. $30 \%$ glycerol was added to solution in relation to dry weight of hypromellose. The mixture was heated to $70^{\circ} \mathrm{C}$, kept at this temperature for 10 min under constant stirring of $\mathrm{I}, 200 \mathrm{rpm}$. The solution remained at this condition until it reached laboratory temperature $\left(\sim 25^{\circ} \mathrm{C}\right)$.

The blends were prepared by combination of the individual solutions of hypromellose and cassava starch in ratios I:I, I:9 and 9:I (hypromellose:starch). The final solution was homogenized at 1,000 rpm for $15 \mathrm{~min}$ and then at $20,000 \mathrm{rpm}$ for $5 \mathrm{~min}$. After homogenization, about $40 \mathrm{~g}$ of the solution containing the above polysaccharide was transferred to Plexiglas plates with $15 \mathrm{~cm}$ diameter and kept under an atmosphere at $60 \%$ relative humidity $(\mathrm{RH})$ at $20^{\circ} \mathrm{C}$. The solutions remain in this controlled environment until the complete evaporation of the solvent with the formation of biofilms, which happened after about 6 days. Subsequently, biofilms were placed under an atmosphere of $\sim 53 \% \mathrm{RH}$ for 5 days.

\section{Mechanical characterization of the films}

Tensile strength (MPa), elongation at break (\%) and modulus of elasticity (MOE) of the films were conducted using a texturometer TA XT2i Stable Micro Systems, and subsequently analyzed in the software (Texture Expert I.15) coupled to the equipment. The films of $100 \mathrm{~mm} \times 25 \mathrm{~mm}$ were pulled at about $0.8 \mathrm{~mm} . \mathrm{s}^{-1}$ starting from an initial separation of $50 \mathrm{~mm}$ claws. The tensile strength of the samples was determined based on ASTM D 882-I2 (20I2). MOE was determined from the tangent of the initial linear of the stress-strain curve, considered as elastic region. Five repetitions for each sample were used. In order to measure the diameters of biofilms, it was used a digital micrometer $(0-30 \mathrm{~mm})$ with $0.001 \mathrm{~mm}$ resolution, by which 20 random measures was obtained per specimen (EUN; WEIBEL, 2009). The specimens were placed in a desiccator containing saturated saline magnesium nitrate hexahydrate (leading to $53 \% \mathrm{RH}$ in the desiccator) solution at $25^{\circ} \mathrm{C}$ for 4 days. 


\section{Microstructural analysis of the films}

The study of the microstructure is essential for understanding the performance of the films, looking for the interaction between the constituent materials. Scanning electron microscopy (SEM) was used to evaluate the fracture surface of the films subjected to tensile tests. The fracture surface was assessed by scanning electron microscopy (SEM, Zeiss LEO EVO 40 XVP, Germany). The accelerating voltage applied was $20 \mathrm{kV}$. The Sputter coating technique using gold was performed for sample preparation. Secondary electron (SE) detector was selected for analyzing the cross section and surface of the samples.

\section{RESULTS AND DISCUSSION}

\section{Properties of the cassava starch and hypromellose}

The cassava starch used for preparing the biofilms presented an amylose content of $14.5 \%$, slightly bellow those found in literature (I6-20\%) (MALI et al., 20I0). The amount of the amylopectin of cassava starch may vary from 80 to $83 \%$ (MAMADOU, 1994), however the amylopectin content found for the starch used in this work was $85.9 \%$. These differences in values are due to different analytical methods used, age and variety of plants (PERONI et al., 2006). The levels found for moisture, lipids, ash and protein were $12.90 \%, 0.31 \%, 0.24 \%$ and $3.40 \%$ respectively. Chemical analysis of hypromellose showed that it had $92.3 \%$ carbohydrates, $7.4 \%$ moisture content, $0.1 \%$ fat, $0.1 \%$ ash and $0.6 \%$ protein.

\section{Properties of the cellulose nanocrystals}

The distribution of diameter and length of the cellulose nanocrystals is shown in Figures $2 \mathrm{~A}$ and $2 \mathrm{~B}$, respectively. It was observed that approximately $80 \%$ of cellulose nanocrystals showed diameter of around 30 $\mathrm{nm}$, while $68 \%$ of these nanocrystals exhibited values of up to $200 \mathrm{~nm}$ length.

The yield of cellulose nanocrystals was determined by weight difference, obtaining $\sim 65 \%$ yield with respect to the starting milled fibers, probably due to disintegration of the amorphous cellulose and degradation of the crystalline region during the hydrolysis. Nanocrystals agglomeration is observed in the LM image (Figure 2C) of the cellulose nanocrystals obtained after $30 \mathrm{~min}$ of acid hydrolysis reaction. Residual pieces of fibers are observed (Figure 2C) as result of the incomplete acid hydrolysis of the cellulose fibers, probably when starting fiber presents larger diameters or large portions of fiber cell wall that are not easily deconstructed.

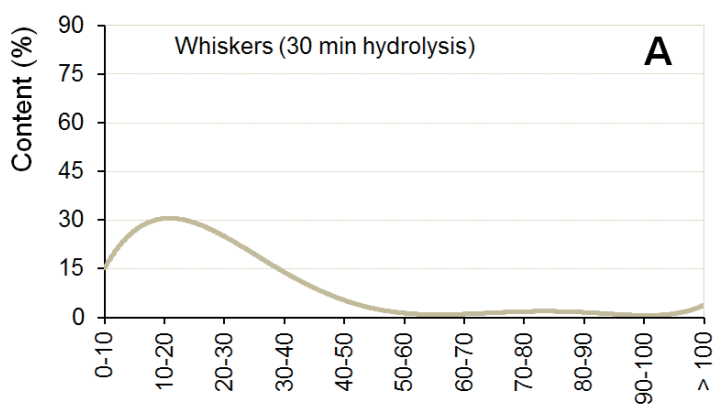

Diameter $(\mathrm{nm})$
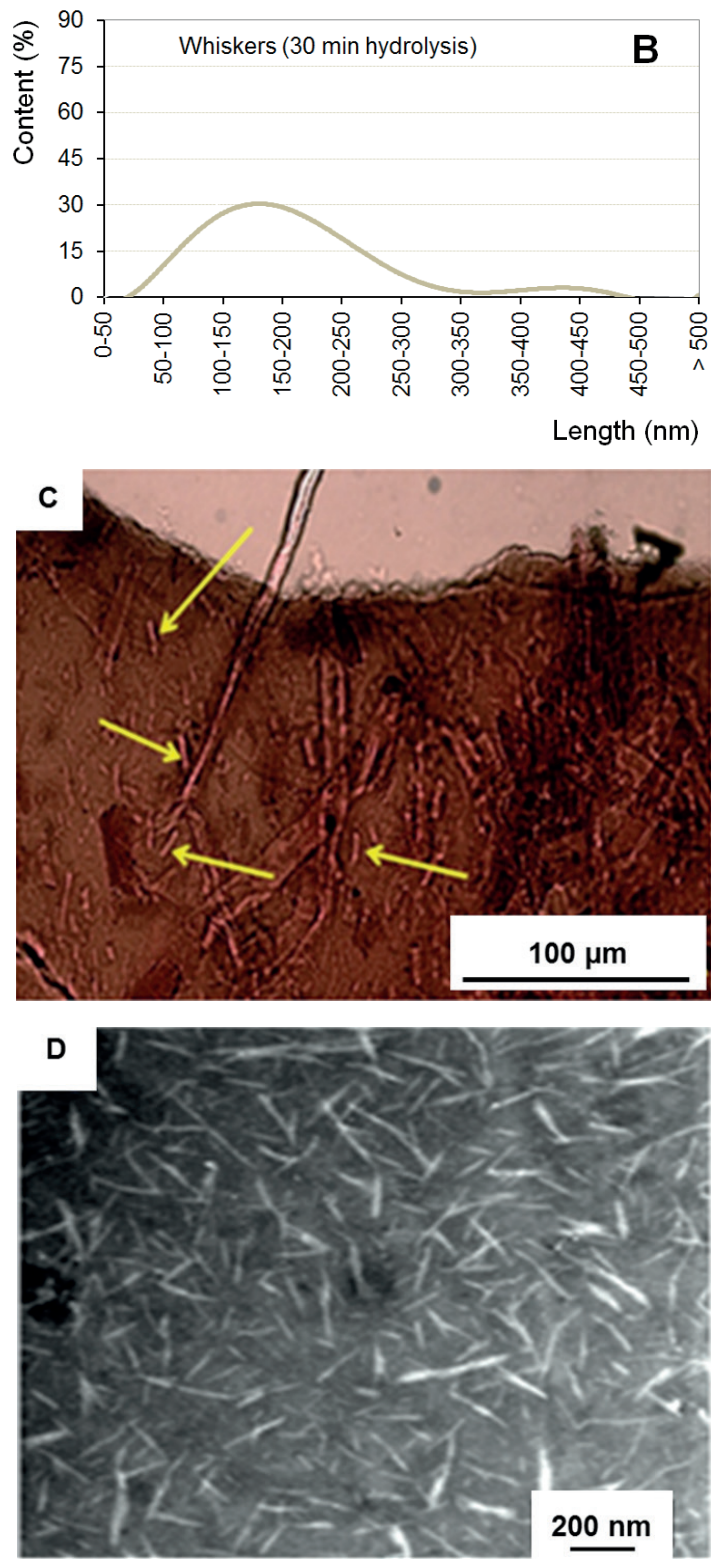

FIGURE 2 Diameter (A) and length (B) distribution of the cellulose nanocrystals; (C) light microscopy micrograph (LM) of a cellulose nanocrystal film (arrows indicate residual fibers were not completely hydrolyzed); (D) transmission electron microscopy (TEM) micrograph of cellulose nanocrystals. 
Cellulose nanocrystals were observed in a transmission electron microscope (TEM) and the result can be seen in Figure 2D, which shows the individualized cellulose nanocrystals and a needle-like shape due to degradation of glucose chains in amorphous cellulose structures by the sulfuric acid. The average diameter and length of the nanocrystals after 30 min of hydrolysis was $15 \pm 6 \mathrm{~nm}$ and $175 \pm 38 \mathrm{~nm}$, respectively, giving an aspect ratio (AR) of about 12. This $A R$ is similar to cellulose nanocrystals extracted from ramie (RA 12) (MENEZES et al., 2009) and from Eucalyptus sp. (BECK-CANDANEDO et al., 2005).

$X$-ray diffractograms (XRD) of the samples (fibers and cellulose nanocrystals) are shown in Figure 3 . The amorphous fraction is related to the intensity at $2 \theta=18^{\circ}$ and $2 \theta=20^{\circ}$ because there is essentially no crystalline diffraction at this region (FRENCH, 20I4). The amorphous fraction appearing at around $2 \theta=18^{\circ}$ suggests that majority of this cellulose exists in I $\beta$ cellulose polymorph (FRENCH, 2014). The XRD patterns of the samples present an amorphous broad hump and crystalline peaks that are typical of semicrystalline materials. Both samples exhibited a sharp peak at $2 \theta=22.6^{\circ}$, which is assigned to the (002) lattice plane of cellulose I. XRD data showed some variation in the position of the cellulose I (002) peak for cellulose nanocrystals (Figure 3 ) which was attributed to reduction in size of the crystalline cell, and suggest the formation of crystallites with different sizes, being predominantly smaller than those found in the starting fibers (DRIEMEIER et al., 20II). This may explain the increased flexibility for samples containing cellulose nanocrystals as a reinforcing agent, suggesting an approximation of the cellulose chains due to the removal of hemicelluloses and lignin (MARIANO et al., 2016). (See Figure 5 and Table 2). Both the starting fibers and hydrolyzed samples did not exhibit any variation in this polymorph type. This happened due to removal of the low molecular weight components and amorphous phases, respectively (WANG et al., 2007b).

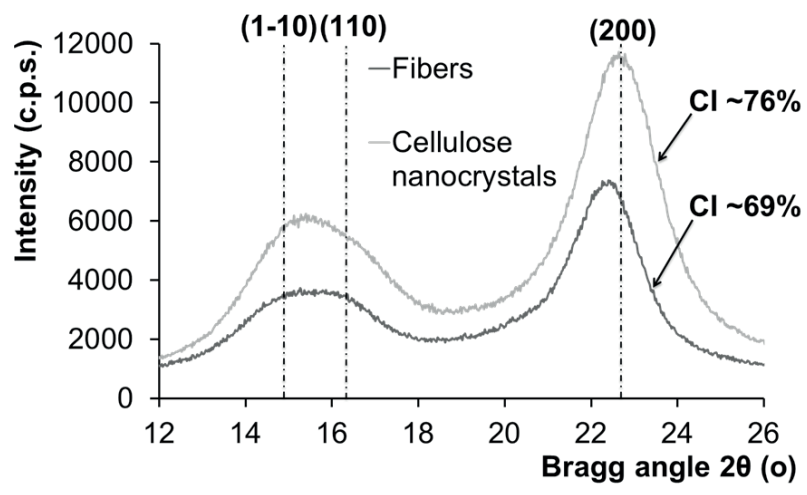

FIGURE 3 X-ray diffractograms (XRD) of the Eucalyptus kraft pulp fibers (before acid hydrolysis) and cellulose nanocrystals (after acid hydrolysis).
Thermal analysis of the starting Eucalyptus fibers and cellulose nanocrystals (Figure 4) showed that acidic hydrolysis decreased the initial degradation temperature $\left(T_{\text {onset }}\right)$ of cellulose nanocrystals, this was also observed by Teixeira et al. (2010) for nanocrystals of cellulose cotton fibers. Thermogravimetry (Figure 4A) of cellulose nanocrystals showed two stages of thermal degradation. The first stage occurred at temperatures of 150 $350^{\circ} \mathrm{C}$, with a weight loss of about $40 \%$ for cellulose nanocrystals. The second stage was between $350-525^{\circ} \mathrm{C}$, and no thermal event was observed at temperatures above $550^{\circ} \mathrm{C}$ with curves becoming constant.

As can be seen in the derivative thermogravimetry curves (DTG) (Figure 4B), the decomposition of the starting Eucalyptus fibers and ensuing cellulose nanocrystals occurred mainly in two stages, indicating the presence of different components that can be degraded at different temperatures. The initial temperature of degradation $\left(T_{\text {onset }}\right)$ of cellulose nanocrystals was lower, from 180 to $230^{\circ} \mathrm{C}$, which is due to the thermal degradation of cellulose nanocrystals containing sulfate groups occurs at lower temperatures (ROMAN; WINTER, 2004; WANG et al., 2007a), leading to the reactions of dehydration that release water and catalyze degradation reactions of cellulose (CORREA et al., 2010). Thus the replacement of $\mathrm{OH}$ groups with sulfate groups decreases the activation energy for degradation of the cellulose chains (WANG et al., 2007b). Due the fact that initial temperature of thermal degradation is low, the use of cellulose nanocrystals produced here by hydrolysis with sulfuric acid, in the polymeric matrix is limited to the ones that do not require elevated temperatures (above $180^{\circ} \mathrm{C}$ ) for processing.
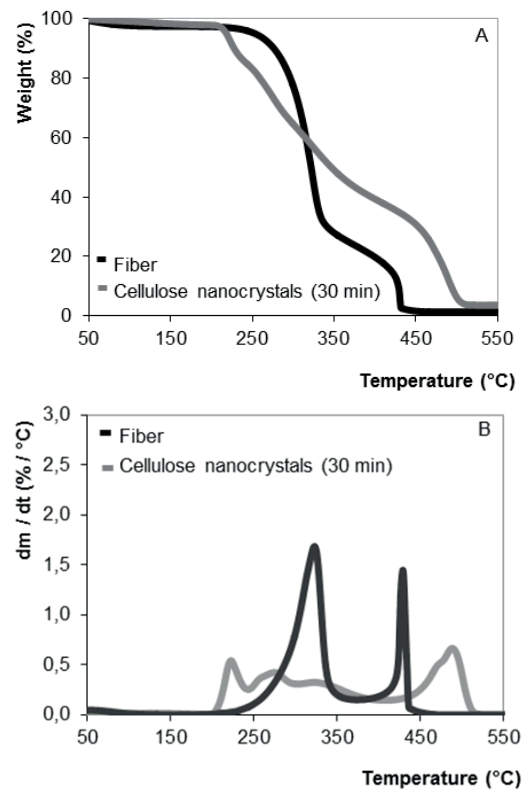

FIGURE 4 Thermogravimetry (A) and derivative thermogravimetry - DTG (B) of the starting Eucalyptus pulp fibers and cellulose nanocrystals. 


\section{Film characteristics}

Different matrices were tested before reinforcement with cellulose nanocrystals as presented in Figure 5A and Table 2. It was observed that the cassava starch film, and the BI:9 film did not show such a high deformation as films developed using the blends B9:I, $B I: I$, and the control with just hypromellose. Films made with hypromellose showed higher tensile strength and elongation at break. Films prepared with the BI: I blend presented lower MOE and tensile strength, and then the B9:I blend was the one chosen for reinforcement with nanocrystals. Mechanical performance of the blend films reinforced with I, 3 and 10\% (w/w) of cellulose nanocrystals is presented in Figure 5B and Table 2.
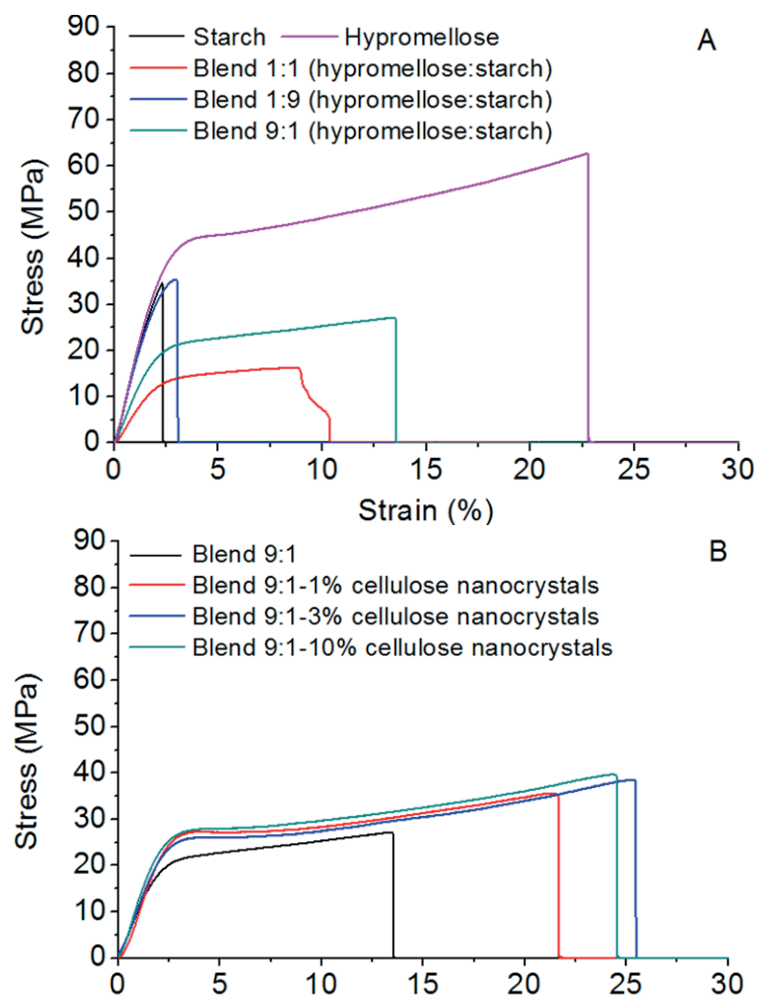

FIGURE 5 Stress vs. strain curves of the control and blend films (A); and after reinforcement with different contents (I, 3 and $10 \%$ ) of cellulose nanocrystals (B).

Comparing recently prepared starch films with others stored for long time, it was observed that the long time stored films undergo the action of the recrystallization phenomenon and films are stiffer. This increase in the pure starch film rigidity can be attributed to the recrystallization process occurring in the starch matrix, as reported by Jiménez et al. (2010). An alternative is the addition of other polymers to the matrix; hence blends prepared with hypromellose can be used in the control of recrystallization of the films (JIMÉNEZ et al., 2012; HUO et al., 20I5).
TABLE 2 Average and standard deviation values of mechanical properties obtained by the tensile test of the starch films $(A)$, hypromellose $(H)$ and their blends $(B)$.

\begin{tabular}{cccc}
\hline Samples & $\begin{array}{c}\text { MOE } \\
(\mathrm{MPa})\end{array}$ & $\begin{array}{c}\text { Tensile strength } \\
(\mathrm{MPa})\end{array}$ & $\begin{array}{c}\text { Elongation at break } \\
(\%)\end{array}$ \\
\hline H & $18.8 \pm 1.1$ & $62.6 \pm 0.7$ & $22.7 \pm 1.5$ \\
A & $17.5 \pm 0.9$ & $34.6 \pm 2.5$ & $2.2 \pm 0.2$ \\
BI:9 & $16.4 \pm 0.6$ & $32.5 \pm 0.6$ & $2.2 \pm 0.6$ \\
B9:I & $10.3 \pm 2.4$ & $27.1 \pm 3.9$ & $13.3 \pm 1.5$ \\
B9:I-1\% & $13.1 \pm 0.8$ & $35.5 \pm 3.6$ & $21.3 \pm 2.7$ \\
B9:I-3\% & $12.2 \pm 0.4$ & $38.5 \pm 1.5$ & $25.2 \pm 1.9$ \\
B9:I-10\% & $13.4 \pm 0.7$ & $39.6 \pm 2.9$ & $24.3 \pm 2.3$ \\
\hline
\end{tabular}

$\mathrm{MOE}=$ modulus of elasticity; $\mathrm{H}=$ hypromellose; $\mathrm{A}=$ cassava starch; $\mathrm{BI}: 9=\mathrm{Blend}$ I hypromellose: 9 cassava starch; B9: I=Blend 9 hypromellose: I cassava starch; BI: I = Blend I hypromellose: I cassava starch; B9: I- I\%=Blend 9 hypromellose: I cassava starch $+1 \%$ cellulose nanocrystals; B9:I-3\%=Blend 9 hypromellose: $I$ cassava starch $+3 \%$ cellulose nanocrystals; $\mathrm{B} 9: 1-10 \%=$ Blend 9 hypromellose: 1 cassava starch $+10 \%$ cellulose nanocrystals.

Comparing the performance of the films obtained from reinforced blends with cellulose nanocrystals and unreinforced matrices, it has been observed an increase in flexibility (MOE) and elongation at break of the reinforced films. Cellulose nanocrystals increased considerably the elongation at break of the films. When comparing the reinforced films with films made only with the blend, it is noted that a concentration of $1 \%$ and $3 \%$ cellulose nanocrystals leads to an increase of $31 \%$ and $42 \%$ in the tensile strength and $60 \%$ and $90 \%$ in the elongation at break, respectively. It was also observed that the reinforcement $(1 \%, 3 \%$ and $10 \%$ of cellulose nanocrystals) favored a higher tensile strength (about 36,38 and $40 \mathrm{MPa}$, respectively), which represents an increase of up to $46 \%$ of modulus of rupture, when compared to the unreinforced blend.

The reinforced films with 10\% cellulose nanocrystals led to $46 \%$ increase in tensile strength and $82 \%$ in deformation ( $8 \%$ less than the film with $3 \%$ nanocrystals). These data showed that the reinforcements with $1 \%$ and $3 \%$ were more efficient. This phenomenon could be attributed to increased sensitivity of the films to moisture by increasing the nanocrystals content (which are hydrophilic) and the potential for plasticizing with moisture absorption. However, increasing the ductility of the film should also result on loss of stiffness, but this was not observed. Bilbao-Sainz et al. (20I I) attributed this phenomenon to the high surface area of the smaller whiskers with the blend promoting the formation of hydrogen bonds between the polysaccharides and the cellulose whiskers, which might have lead to a higher efficiency of the stress transfer from the matrix to the fibers. Another explanation could be related to the homogeneity of the reinforcing material dispersed within the polymeric matrix and creating some network with 
nanocrystals probably by hydrogen bonds formed between nanocrystals. The increased concentration of cellulose nanocrystals in this network arrangement increased reinforcement, because of the large interaction between the nanoparticles and the matrix, and thus reducing the mobility of the polymer chains of the matrix and mainly due to mechanical percolation phenomenon of the cellulose nanocrystals. Compositions with $10 \%$ nanocrystals probably was adversely affected by sedimentation and deficiencies in their dispersion into the matrix, causing an increase of defects in the film, increasing the stiffness of the material and decreasing mechanical strength.

The micrographs obtained by SEM (Figure 6) show the films after the tensile tests and such images reveal that the films $A$ and $B I: 9$ showed a fragile behavior indicated by the brighter surface of the fractured region. The other films had their fracture surfaces characterized by the appearance of deformations in the shape of thin layers (Figure 6B), small cavities (Figure 6C), and small irregularities (Figures 6C and 6D), probably due to rearrangement of the molecules during traction. For better visualization of the irregularities of the affected region it was carried out increases in fracture areas, as in Figure 6B and Figure 6D, right.
When the fracture surfaces of samples reinforcement with cellulose nanocrystals were analyzed, it was observed greater regularity on the surface of these films, when compared to non-reinforced films. It indicates that the nanocrystals were dispersed in the matrices and contribute to cohesion of the matrix molecules, creating a smoother surface.

The homogeneous matrix of the films is a good indicator of its structural integrity that promotes improved mechanical properties (MALI et al., 2002). This information corroborates the results obtained in the mechanical tests, since there was a significant increase in tensile strength and elongation at break with a slight increase of MOE.

\section{CONCLUSION}

Cellulose nanocrystals were successfully isolated using acid hydrolysis of Eucalyptus pulp fibers. Varying the amounts of hypromellose and starch content in the blends influenced the mechanical properties of the films. It was observed that the content of starch in the blends promoted wide variations in the modulus of elasticity and maximum strain, leading to more ductile

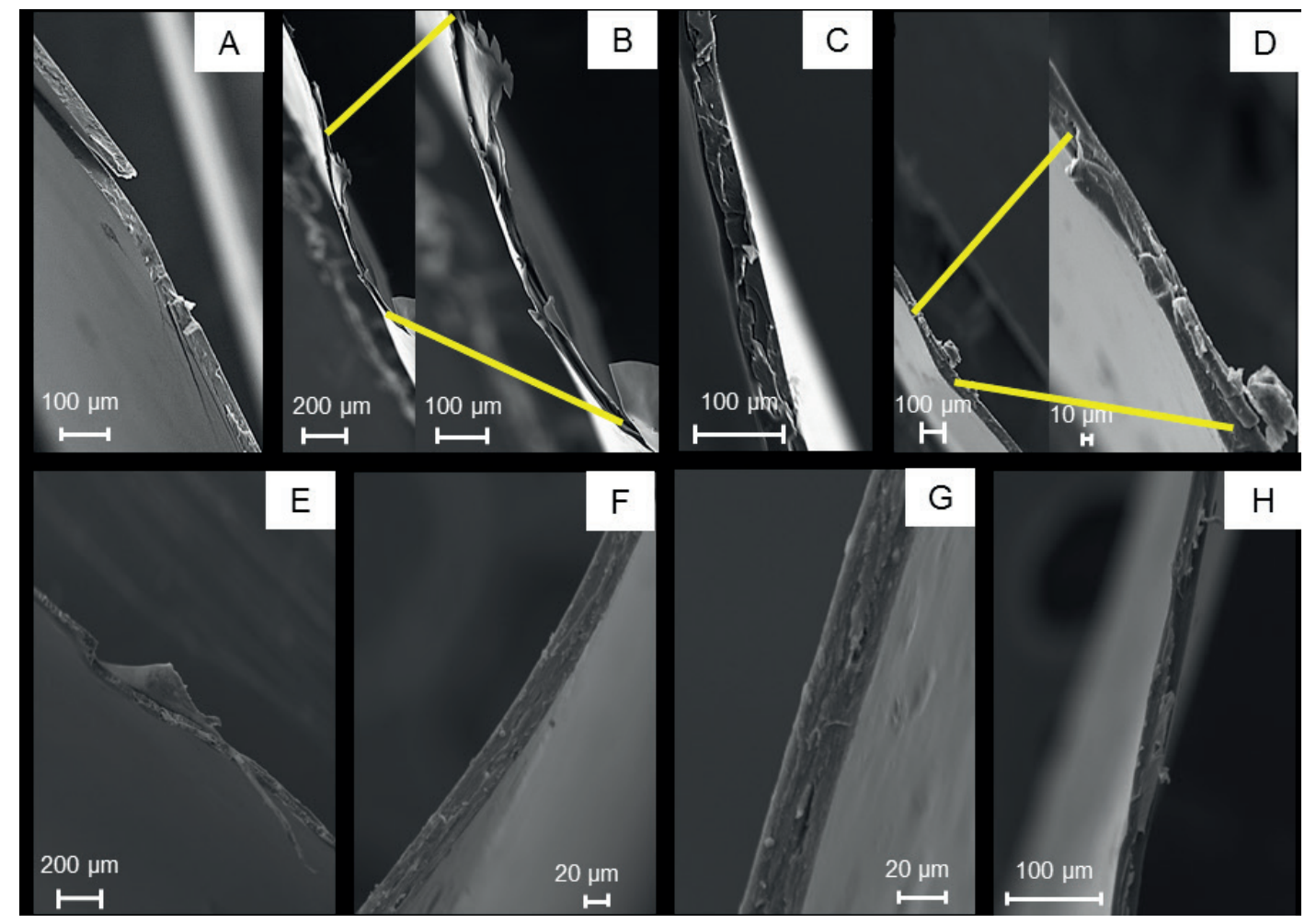

FIGURE 6 Micrographs of scanning electron microscopy (SEM) of the film fracture surfaces: A) A = cassava starch; B) BI:I = blend I hypromellose:I cassava starch; C) B9:I = blend 9 hypromellose:I cassava starch; D) H = hypromellose; and E) BI:9= blend I hypromellose:9 cassava starch and reinforced with cellulose nanocrystals in the proportions: F) B9:I-I\% = blend 9 hypromellose:I cassava starch + I\% cellulose nanocrystals; G) B9:I-3\% = blend 9 hypromellose:I cassava starch $+3 \%$ cellulose nanocrystals; and H) B9:I-10\% = blend 9 hypromellose: I cassava starch + 10\% cellulose nanocrystals. 
films. The maximum tensile strength of the films had greater loss when the proportion of hydroxipropil methylcellulose (hypromellose) and starch in the blend had the same ratio. The cellulose nanocrystals promoted further strengthening, lower stiffness and greater ductility in film with the blend B9:I (hypromellose:starch). The increase in the mechanical properties was not directly proportional to the amount of cellulose nanocrystals tested here. The present study contributed with information about cellulose nanocrystals, and further progress of this approach could improve the performance of nanocomposites based on hypromellose and starch for development of new and engineered materials.

\section{REFERENCES}

ALEMDAR, A.; SAIN, M. Isolation and characterization of nanofibers from agricultural residues - Wheat straw and soy hulls. Bioresource Technology, v. 99, p. I664-2167, 2008.

AMERICAN SOCIETY FOR TESTING AND MATERIALS [ASTM]. 2012. D882-12, Standard Test Method for Tensile Properties of Thin Plastic Sheeting. ASTM International, West Conshohocken, PA, USA.

ARANTES, A. C. C.; ALMEIDA, C.; DAUZACKER, L.; BIANCHI, M. L.; WOOD, D.; WILLIAMS, T.; ORTS, W. J.; TONOLI, G. H. D. Renewable hybrid nanocatalyst from magnetite and cellulose for treatment of textile effluents. Carbohydrate Polymers, p. 101-107, 2017.

ASSOCIATION OF OFFICIAL ANALYTICAL CHEMISTS [AOAC]. Official methods of analysis (16th ed). Protocol 923.03: ash. Arlington; 2000.

ASSOCIATION OF OFFICIAL ANALYTICAL CHEMISTS [AOAC]. Official methods of analysis (16th ed). Protocol 945. 15: moisture content. Arlington; 2000.

AVEROUS, L.; BOQUILLON, N. Biocomposites based on plasticized starch: thermal and mechanical behaviours. Carbohydrate Polymers, v. 56, n. 2, p. I I I-I 22, 2004.

AYDIN, A. A.; ILBERG, V. Effect of different polyol-based plasticizers on thermal properties of polyvinyl alcohol: starch blends. Carbohydrate Polymers, v. I36, p. 44I-448, 2016.

BECK-CANDANEDO, S.; ROMAN, M.; GRAY, D. G. Effect of reaction conditions on the properties and behavior of wood cellulose nanocrystal suspensions. Biomacromolecules, v. 6, n. 2, p. 1048-1054, 2005.

BILBAO-SAINZ, C.; BRAS, J.; WILLIAMS, T.; SENECHAL, T.; ORTS, W. HPMC reinforced with different cellulose nanoparticles. Carbohydrate Polymers, v. 86, n. 4, p. I549I557, 201 I.

BONDESON, D.; MATHEW, A.; OKSMAN, K. Optimization of the isolation of nanocrystals from microcrystalline cellulose by acid hydrolysis. Cellulose, v. I3, p. I7I-I80, 2006.
BUFALINO, L.; SENA NETO, A. R.; TONOLI, G. H. D.; FONSECA, A. S.; COSTA, T. G.; MARCONCINI, J. M.; COLODETTE, J. L.; LABORY, C. R. G.; MENDES, L. M. How the chemical nature of Brazilian hardwoods affects nanofibrillation of cellulose fibers and film optical quality. Cellulose, v. 22, n. 6, p. 3657-3672, 2015.

BUFALINO, L.; TONOLI, G. H. D.; COSTA, T. G.; PROTÁSIO, T. P.; SENA NETO, A. R.; MARCONCINI, J. M.; GUIMARÃES, M.; MENDES, L. M. Nanocellulose Films from Amazon Forest Wood Wastes: Structural and Thermal Properties. Key Engineering Materials, v. 668, p. II0-II7, 2015.

BUSCHLE-DILLER, G.; ZERONIAN, S. H. Enhancing the reactivity and strength of cotton fibers. Journal of Applied Polymer Science, v. 45, n. 6, p. 967-979, 1992.

CHOI, W. S.; SINGH, S.; LEE, Y. S. Characterization of edible film containing essential oils in hydroxypropyl methylcellulose and its effect on quality attributes of 'Formosa' plum (Prunus salicina L.). Food Science and Technology, v. 70, p. $213-222,2016$.

CORRÊA, A. C.; TEIXEIRA, E. M.; PESSAN, L. A.; MATTOSO, L. H. C. Cellulose nanofibers from curaua fibers. Cellulose, v. 17, n. 6, p. II83-1192, 2010.

DONIA, A. M.; ATIA, A. A.; ABOUZAYED, F. I. Preparation and characterization of nano-magnetic cellulose with fast kinetic properties towards the adsorption of some metal ions. Chemical Engineering Journal, v. 191, p. 22-30, 2012.

DRIEMEIER, C.; PIMENTA, M. T. B.; ROCHA, G. J. M. Evolution of cellulose crystals during prehydrolysis and soda delignification of sugarcane lignocellulose. Cellulose, v.18, n. 6, p. I509-1519, 201 I.

EUN, Y. J.; WEIBEL, D. B. Fabrication of microbial biofilm arrays by geometric control of cell adhesion. Journal of Materials Science, v. 25, n. 8, p. 4643-4654, 2009.

FONSECA, C. S.; SILVA, T. F.; SILVA, M. F.; OLIVEIRA, I. R. C.; MENDES, R. F.; HEIN, P. R. G.; MENDES, L. M.; TONOLI, G. H. D. Micro/nanofibrilas celulósicas de eucalyptus em fibrocimentos extrudados. Cerne, v.22, p. 59-68, 2016.

FORTUNATI, E.; RINALDI, S.; PELTZER, M.; BLOISE, N.; VISAI, L.; ARMENTANO, I.; JIMÉNEZ, A.; LATTERINI, L.; KENNY, J. M. Nano-biocomposite films with modified cellulose nanocrystals and synthesized silver nanoparticles. Carbohydrate Polymers, v. I0I, p. II22-1 I33, 20 I4.

FRENCH, A. D. Idealized powder diffraction patterns for cellulose polymorphs. Cellulose, v.2I, n. 2, p. 885-896, 2014.

GILFILLAN, W. N.; MOGHADDAM, L.; BARTLEY, J.; DOHERTY, W. O. S. Thermal extrusion of starch film with alcohol. Journal of Food Engineering, v. 170, p. 92-99, 2016. 
GONÇALVES, P. M.; NOREÑA, C. P. Z; SILVEIRA, N. P.; BRANDELL, A. Characterization of starch nanoparticles obtained from Araucaria angustifolia seeds by acid hydrolysis and ultrasound. Food Science and Technology, v.58, n. I, p. $21-27,2014$.

GUIMARÃES JR. M.; BOTARO, V. R.; NOVACK, K. M.; TEIXEIRA, F. G.; TONOLI, G. H. D. Starch/PVA-based nanocomposites reinforced with bamboo nanofibrils. Industrial Crops and Products, v. 70, p. 72-83, 2015.

GUPTA, V. K.; PATHANIA, D.; SINGH, P.; RATHORE, B. S.; CHAUHAN, P. Cellulose acetate-zirconium (IV) phosphate nano-composite with enhanced photo-catalytic activity. Carbohydrate Polymers, v. 95, n. I, p. 434-440, 2013.

HUO, P.; SAVITSKAYA, T.; GOTINA, L.; REZNIKOV, I.; GRINSHPAN, D. Rheological Properties of Casting Solutions for Starch Edible Films Production. Open Journal of Fluid Dynamics, v. 5, p. 58-67, 2015.

JIMÉNEZ, A.; FABRA M. J.; TALENS, P.; CHIRALT, A. Edible and biodegradable starch films: a review. Food and Bioprocess Technology, v. 5, n. 6, p. 2058-2076, 2012.

JIMÉNEZ, A.; FABRA, M. J.; TALENS, P.; CHIRALT, A. Effect of lipid self-association on the microstructure and physical properties of hydroxypropyl-methylcellulose edible films containing fatty acids. Carbohydrate Polymers, v. 82, n. 3, p. 585-593, 2010.

KANMANI, P.; RHIM, J. W. Properties and characterization of bionanocomposite films prepared with various biopolymers and $\mathrm{ZnO}$ nanoparticles. Carbohydrate Polymers, v. 106, p. 190-199, 2014.

KJELDAHL, J. Neue Methode zur Bestimmung des Stickstoffs in organischen Körpern. Zeitschrift für analytische Chemie, v. 22, n. I, p. 366-382, I883.

KLEMM, D.; HEUBLEIN, B.; FINK, H. P.; BOHN, A. Cellulose: Fascinating biopolymer and sustainable raw material. Angewandte Chemie International Edition, v. 44, n. 22, p. 3358-3393, 2005.

KU, H.; WANG, H.; PATTARACHAIYAKOOP, N.; TRADA, $M$. A review on the tensile properties of natural fibre reinforced polymer composites. Composites Part B, v. 42 , n. 4, p. 856-873, 201 I.

LAVOINE, N.; DESLOGES, I.; KHELIFI, B.; BRAS, J. Impact of different coating processes of microfibrillated celulose on the mechanical and barrier properties of paper. Journal of Materials Science, v. 49, n. 7, p. 2879-2893, 2014.

MALI, S., GROSSMANN, M. V. E., GARCIA, M. A., MARTINO, M. M., ZARITZKY, N. E. Microstructural characterization of yam starch films. Carbohydrate Polymers, v. 50, n. 4, p. 379-386, 2002.

MALI, S.; GROSSMANN, M. V. E.; YAMASHITA, F. Filmes de amido: produção, propriedades e potencial de utilização. Semina: Ciências Agrárias, v. 3I, n. I, p. I37-156, 2010.
MAMADOU, S. Etude du procédé de fabrication de barquettes a base de produits amylaces expanses, application au manioc. 1994. 53 p. PhD thesis (Dipiome D'Études Approfondies) - L'Ecoie Nationaie Supérieure des Industries Agricoies et Alimentaires, (E.N.S.I.A.), Massy, France.

MARIANO, M.; CERCENA, R.; SOLDI, V. Thermal characterization of cellulose nanocrystals isolated from sisal fibers using acid hydrolysis. Industrial Crops and Products, v.94, p. 454-462, 2016.

MARTÍNEZ, C.; CUEVAS, F. Evaluación de la calidad culinaria y molinera del arroz: Guía de estudio. CIAT - Centro Internacional de Agricultura Tropical, 1989. 75 p.

MARTINEZ, M. O.; AYERDI, S. S.; AGAMA, E. C.; GONI, I.; BELLO, P. L. A. Unripe banana flour in the ingredient to the increase of carbohydrate indigestible paste. Food Chemistry, v. II3, p. I2I-I26, 2009.

MENEZES, A. J.; PASQUINI, D.; CURVELO, A. A. S.; GANDINI, A. Self-reinforced composites obtained by the partial oxypropylation of cellulose fibers: I. Characterization of the materials obtained with different types of fibers. Carbohydrate Polymers, v. 76, n. 3, p. 437-442, 2009.

MIRMEHDI, S.; HEIN, P. R. G. H.; SARANTÓPOULOS, C. I. G. L.; DIAS, M. V.; TONOLI, G. H. D. Cellulose nanofibrils/ nanoclay hybrid composite as a paper coating: Effects of spray time, nanoclay content and corona discharge on barrier and mechanical properties of the coated papers. Food Packaging and Shelf Life, In Press, 2017.

NIKOLAJASKI, M.; WOTSCHADLO, J.; CLEMENT, J. H.; HEINZE, T. Amino-functionalized cellulose nanoparticles: preparation, characterization, and interactions with living cells. Macromolecular Bioscience, v. 12, n. 7, p. 920925, 2012.

PEREZ, S.; BERTOFT, E. The molecular structures of starch components and their contribution to the architecture of starch granules: A comprehensive review. Starch, v. 62, n. 8, p. 389-420, 2010.

PERONI, F. H. G.; ROCHA, T. S.; FRANCO, C. M. L. Some structural and physicochemical characteristics of tuber and root starches. Food Science and Technology International, v. 12, n. 6, p. 505-5।3, 2006.

PRACHAYAWARAKORN, L.; SANGNITIDEJ, P.; BOONPASITH, P. Properties of thermoplastic rice starch composites reinforced by cotton fiber or low-density polyethylene. Carbohydrate Polymers, v. 8I, n. 2, p. 425-433, 2010

ROMAN, M.; WINTER, W. T. Effect of sulfate groups from sulfuric acid hydrolysis on the thermal degradation behavior of bacterial cellulose. Biomacromolecules, v. 5, n. 5, p. |67|-I677, 2004. 
ROMERO-BASTIDA, C. A.; BELLO-PÉREZ, B. L. A.; VELAZQUEZA, G.; ALVAREZ-RAMIREZC, J. Effect of the addition order and amylose content on mechanical, barrier and structural properties of films made with starch and montmorillonite. Carbohydrate Polymers, v. 127, p. 195-201, 2015.

ROZ, A. L. D.; FERREIRA, A. M.; YAMAJI, F. M.; CARVALHO, A. J. F. Compatible blends of thermoplastic starch and hydrolyzed ethylene-vinyl acetate copolymers. Cabohydrate Polymers, v. 90, n. I, p. 34-40, 2012.

SCAN Standard C 1:77 Kappa number of pulp. Scandinavian Pulp, Paper and Board Testing Committee, Stockholm, Sweden, 1977.

SCAN Standard C 4:6I Pentosans in pulp. Scandinavian Pulp, Paper and Board Testing Committee, Stockholm, Sweden, 196I.

SCAN Standard C 6:62 Ash in wood and pulp. Scandinavian Pulp, Paper and Board Testing Committee, Stockholm, Sweden, 1962.

SCAN Standard C 7:62 Dichloromethane extract of pulp. Scandinavian Pulp, Paper and Board Testing Committee, Stockholm, Sweden, 1962.

SCATOLINO, M. V.; SILVA, D. W.; BUFALINO, L.; TONOLI, G. H. D.; MENDES, L. M. Influence of cellulose viscosity and residual lignin on water absorption of nanofibril films. Procedia Engineering, v. 200, p. I55-16I, 2017a.

SCATOLINO, M. V.; BUFALINO, L.; MENDES, L. M.; GUIMARÃES JR., M.; TONOLI, G. H. D. Impact of nanofibrillation degree of eucalyptus and Amazonian hardwood sawdust on physical properties of cellulose nanofibril films. Wood Science and Technology, v. 5I, p. I-2I, 20I 7b.

SHIT, S. C.; SHAH, P. M. Edible Polymers: Challenges and Opportunities. Journal of Polymers, v. 20I4, p. I-I3, 20 I4.

SHOJAEE-ALIABADI, S.; HOSSEINI, H.; MOHAMMADIFAR, M. A.; MOHAMMADI, A.; GHASEMLOU, M.; OJAGH, S. M.; HOSSEINI, S. M.; KHAKSAR, R. Characterization of antioxidant antimicrobial K-carrageenan films containing Satureja hortensis essential oil. International Journal of Biological Macromolecules, v. 52, p. II6-I24, 2013.

SIQUEIRA, G.; BRAS, J.; DUFRESNE, A. Cellulose whiskers versus microfibrils: influence of the nature of the nanoparticle and its surface functionalization on the thermal and mechanical properties of nanocomposites. Biomacromolecules, v. I0, n. 2, p. 425-432, 2009.

SVENSSON, A.; NICKLASSON, E.; HARRAH, T.; PANILAITIS, B.; KAPLAN, D. L.; BRITTBERG, M.; GATENHOLM, P. Bacterial cellulose as a potential scaffold for tissue engineering of cartilage. Biomaterials, v. 26, n. 4, p. 41943I, 2005.
RAABE, J.; FONSECA, A; BUFALINO, L.; RIBEIRO, C.; MARTINS, M. A.; MARCONCINI, J. M.; MENDES, L. M.; TONOLI, G. H. D. Biocomposite of Cassava Starch Reinforced with Cellulose Pulp Fibers Modified with Deposition of Silica $\left(\mathrm{SiO}_{2}\right)$ Nanoparticles. Journal of Nanomaterials, v. 2015, p. I-9, 2015.

RAABE, J.; FONSECA, A. S.; BUFALINO, L.; RIBEIRO, C.; MARTINS, M. A.; MARCONCINI, J. M.; TONOLI, G.H.D. Evaluation of reaction factors for deposition of silica $\left(\mathrm{SiO}_{2}\right)$ nanoparticles on cellulose fibers. Carbohydrate Polymers, v. II4, p. 424-43I, 20 I4.

TAPPI Useful Method. T 203cm-99: Alpha-, beta- and gamma-cellulose in pulp. Technical Association of the Pulp and Paper Industry, Atlanta, GA, USA, 2009.

TEIXEIRA, E. M.; CORRÊA, A. C.; MANZOLI, A.; LEITE, F. L.; OLIVEIRA, C. R.; MATTOSO, L. H. C. Cellulose nanofibers from white and naturally colored cotton fibers. Cellulose, v. I7, n. 3, p. 595-606, 2010.

TEODORO, A. P.; MALI, S.; ROMERO, N.; CARVALHO, G. M. Cassava starch films containing acetylated starch nanoparticles as reinforcement: Physical and mechanical characterization. Carbohydrate Polymers, v. 126, p. 9-16, 2015.

TONOLI, G. H. D.; TEIXEIRA, E. M.; CORRÊA, A. C.; MARCONCINI, J. M.; CAIXETA, L. A.; SILVA, M. A. P.; MATTOSO, L. H. C. Cellulose micro/nanofibres from Eucalyptus kraft pulp: preparation and properties. Carbohydrate Polymers, v. 89, n. I, p. 80-88, 2012.

TONOLI, G. H. D.; HOLTMAN, K. M.; GLENN, G.; FONSECA, A. S.; WOOD, D.; WILLIAMS. T.; SA, V. A.; TORRES, L.; KLAMCZYNSKI, A.; ORTS, W. J. Properties of cellulose micro/nanofibers obtained from eucalyptus pulp fiber treated with anaerobic digestate and high shear mixing. Cellulose, v. 23, p. I-18, 2016.

WANG, B.; SAIN, M.; OKSMAN, K. Study of structural morphology of hemp fiber from the micro to the nanoscale. Applied Composite Materials, v. I4, p. 89103, 2007b.

WANG, N.; DING, E.; CHENG, R. Thermal degradation behaviours of spherical cellulose nanocrystals with sulfate groups. Polymer, v. 48, n. 12, p. 3486-3493, 2007a.

YAN, L. Plain concrete cylinders and beams externally strengthened with natural flax fabric reinforced epoxy composites. Materials and Structures, v. 49, n. 6, p. 2083-2095, 2015.

YAN, L.; SU, S.; CHOUW, N. Microstructure, flexural properties and durability of coir fiber reinforced concrete beams externally strengthened with flax FRP composites. Composites Part B: Engineering, v. 80, p. 343-354, 2015 a. 
YAN, L.; CHOUW, N.; JAYARAMAN, K. Effect of UV and water spraying on the mechanical properties of flax fabric reinforced polymer composites used for civil engineering application. Materials \& Designe, v. 7I, p. I7-25, 20I5b.
ZENEBO, N. O.; PASCUET, N. S. Normas analíticas do Instituto Adolfo Lutz. 4. ed. São Paulo: Instituto Adolfo Lutz, 2005. 1020 p. 